Volume 3 No. 1, Juni 2018

P ISSN 2442-594X | E ISSN 2579-5708

http://journal.iainlangsa.ac.id/index.php/tibyan

DOI: $10.32505 /$ tibyan.v3i1.484

\title{
ISSUES ON WOMEN AND PROBLEMS IN WORKPLACE FROM ISLAMIC POINT OF VIEW
}

\author{
Isu perempuan dan Problematikanya di Tempat Kerja dalam Pandangan Islam
}

\author{
Angraini binti Ramli \\ International Islamic University Malaysia \\ angrainiramli@gmail.com \\ Radwan Jamal Elatrash \\ International Islamic University Malaysia \\ radwan@iium.com
}

\begin{abstract}
Abstrak
Perkembangan zaman dan meningkatnya pergerakan ekonomi membuka peluang seluas-luasnya bagi perempuan untuk turut andil di dalamnya. Tenaga perempuan yang turut diberdayakan dalam berbagai sektor yang kemudian fenomena ini ternyata berdampak positif dan negative pada lini kehidupan lainnya seperti sisi ekonomi, sosial, pendidikan dan pembangunan. Islam sendiri memiliki jawaban atas kendala sosial yang disandarkan kepada keterlibatan perempuan di ranah publik. Maka kajian ini bertujuan untuk memaparkan beberapa konflik yang terjadi ketika perempuan terjun ke dunia pekerjaan dan bagaimana Islam menyediakan aturan yang murni bertujuan untuk melindungi perempuan agar tetap berada pada fitrahnya namun tetap menyelarasi keperluan perempuan seiring berkembangnya zaman
\end{abstract}

Kata Kunci: Perempuan, Pekerjaan, Publik, Perspektif Islam

\begin{abstract}
The globalization and economic growth develop bigger chance especially to women to take a part in playing their role. Women education and strength are well established nowadays which can be potentially empowered in many public sectors. These phenomenahave caused positive and negative impacts to their live economically and socially. Islam provides the solutionsfor those social problems which effected by women involvement in public. This research describes several problemsappearingbecause of women taking their part in public sectors and how Islam provides the regulations and rules to protect the women's fitrah and meet women development needs today.
\end{abstract}

Keywords: Woman, Job, Public, Islam Perspective 


\section{Introduction}

The topic about gender has become the most popular topic discussed. More over in this globalization era, where women are able toobtain high education as men, earn a big salary as men, and even hold a higher position than men in certain public sectors.The world develops technologically and economically and makes wider opportunity for both genders toapply their abilities.

As defined by Central Agency of Statistics (BPS, 2009) in accordance with International Labor Organization (ILO), workers are all people at age 15 or above. They aredivided into 3 stages as follows:

1. Full employed, who has more than 35 hours of total working hours in a week with certain earning based on cope of duties.

2. Under employed, who has less than 35 hours of working time in a week.

3. Unemployed, who has only 0-1 hour working hours in a week.

Based on this definition, BPS has stated that on August 2016, the quantity of women residences in Indonesia reached 94,72 million and 94,37 million for the men. It means, women which covered half of total residences in Indonesia is a fundamental development asset. The development relied on the realization of half residencies potency. If women fail to realize the potency of half residences, they will fail to develop. ${ }^{1}$

In sector of education, the percentage of women at age 25 and above who pursue higher education and got a certification from universities is $7,92 \%$. This percentageis higher than the percentage of men which only reach $7,91 \% .^{2}$ This factshould become a powerful motivation for every woman to apply their abilities and knowledge whether in domestic or public sectors.

The factors motivating women to work or to be employed are related to at least 3 main points. First; education. The higher education women obtain and the higher qualification they hold, the more probabilities to be employed they have. Thus, the higher education they have means the higher impact on the time they have. By holding such high qualification and education, they will be paid higher. Education also have positiveeffect to productivity. Those with high qualification and education tend to have a higher productivity than those who don't. This is the main reason why women with high education are willing to work. ${ }^{3}$

The Following reason which stimulated women to work is economic growth. Needs and responsibilities are growing along with the growth of age. Women grows with a responsibility to take care of them self or occasionally also their family. Despite the sustenance is not an obligation for women, but it's not few women who stands up

\footnotetext{
${ }^{1}$ Ema Tusianti, dkk, Kajian Awal Indeks Ketimpangan Gender 2016, Badan Pusat Statisik, pg. 64.

${ }^{2}$ Ema Tusianti, dkk,Kajian Awal Indeks Ketimpangan Gender 2016, Badan Pusat Statistik, pg. 66.

${ }^{3}$ Fitria Majid, Faktor-Faktor Yang Mempengaruhi Keputusan Perempuan Berstatus Menikah Untuk Bekerja (Studi Kasus: Kota Semarang), Undergraduate Thesis, Semarang, Fakultas Ekonomika dan Bisnis, Universitas Diponegoro, Semarang, 2012. Pg. 33-36.
} 
to make a living for their family for many reasons. The not functioning guardian or spouse and high life necessities with low income are the general factors which push them to assist or take a role to execute the family living. It is coincident with what Simanjuntak Pajaman said as quoted by Fitria Majid that the number of dependents in family determines the probability of working women in family. More dependents mean more manpower to make a living. ${ }^{4}$ Family income is another crucial matter, Fitria underlined the explanation by Sumarsono that family income related to determine the number of manpower in family. High family income will decrease the number of manpower in family and vice versa. ${ }^{5}$

Another reason need to be mentioned is about self-existences in social life. Nurul Hidayati said that women have a specific need in social relationship. To be existed in their social life requires a media to fulfill their needs as workplaces and colleagues. Self-actualization is one of many factors which pushes women to step on the career world. From there, they can accept the reward as their career advancement if their showed the good performance. Being creative and innovative, expanding their knowledge, receiving a reward, social acceptance, achievement and accomplishment are the steps to fulfill their self-existence need. ${ }^{6}$

The factors mentioned also can be a valid reason for women to step on career world. Although it is beneficial to themselves even to their family, women existence in public susceptibly invites and creates another problem. Sexual harassment, verbally or non-verbally, physically, visually, or psychologically ${ }^{7}$ has happened commonly in a workplace. Men and women also can have a non-halal-relationship which have a bad effect to those in married status. There are certain issues in uniform also.Sometimes, companies have certain regulations in terms of uniforms. For married women, there are another issues related to their duty in domestic sector as a wife or a mother to their children. They tend to experience a dual role conflict, as a wife and mother in domestic sector and as an employment in public sector. Many cases stated that the women failed to keep balancing between their duties in domestic and public which cause failing in one of the duty.Having an absence presence during the nurturing and educating their kids which caused a weak bond between each other. Parents-children relationship becomes on financial relationship.Unmanaged schedules, being under pressured and feeling stress in workplaces cause chaos in domestic sectors by throwing the tempers

${ }^{4}$ Fitria Majid, Faktor-Faktor Yang Mempengaruhi Keputusan Perempuan Berstatus Menikah Untuk Bekerja (Studi Kasus: Kota Semarang), Undergraduate Thesis, Fakultas Ekonomika dan Bisnis, Universitas Diponegoro, 2012. Pg. 37.

${ }^{5}$ Fitria Majid, Faktor-Faktor Yang Mempengaruhi Keputusan Perempuan Berstatus Menikah Untuk Bekerja (Studi Kasus: Kota Semarang), Undergraduate Thesis, Semarang, Fakultas Ekonomika dan Bisnis, Universitas Diponegoro, 2012. Pg. 35.

${ }^{6}$ Nurul Hidayati, Beban Ganda Perempuan Bekerja (Antara Domestik dan Publik) Jurnal Muwazah, Volume 7, Number 2, December 2015, pg. 112.

${ }^{7}$ Zakaria Ismail, Abdul Malik Habeeb Mohd. Malani Achro. Gangguan Seksual di Tempat Kerja: Defenisi, Kesan dan Langkah Mengatasinya, pg. 6. 
to spouses and kids, for examples. This becomes the root of unhappy married life andunharmonious family life.

\section{Methodology}

This research is a library research which put a special attention to study and review literatures which related to women and work. The study will be in descriptiveanalytic methodology. Then, it will be processed analytically and descriptively. This study will try to solve the problems stated above in the matters of women and work by studying the commentaries from several scholars to Qur'anic verses related to this matters. The data will be analyzed by content analysis method which sorting the data according to the similar theme then describe, review, and criticize to find the suitable formula to be applied as the answers to the stated problem.

\section{Problems Occurred Related to Women in Workplace and The Solution Provided from Islamic Point of View}

Here, the author(s) pointed out two main issues which turned up as problemswhen women step in their feet to workplace, they tend to be a victim of an objectionable act and for those who are married they will face a dual role conflicts between their duty at house and at a work place, also, how to respond to these problems from Islamic point of view.

\section{As a victim of an objectionable act}

Women owns such beauty which created by God. He created this beauty in order to make a balance life chain. This beauty normally will attract the opposite gender and they built the relationship in proper ways. Unfortunately, the sense of beauty was abused and women who owns it was treated as an object. Women are rated by the beauty of their bodies and faces. And sadly, some women know this paradigm and help it to spread. They themselves who expose their beauty to public proudly, they even left and put the sharia aside.

Many cases happened in term of harassment. Sexual harassment is the most common problem happened in such workplace. National Women's Law Center mentioned that sexual harassment is a form of sex discrimination, it includes, unwelcome sexual advances, request for sexual favors or hostile verbal or physical conduct that targets based on gender, whether or not sexual overtures are involved. ${ }^{8}$

Zakaria et el. mentioned that sexual harassment for women started since they were stepping in to the workplace, it was long time ago. But it was not reported as a harassment. America is the first country which reported sexual harassment in the workplace as a sexual discrimination and should be banned. Their study said that an objectionable act such as sexual harassment in working place can be defined in many

\footnotetext{
${ }^{8}$ National Women's Law Center (NWLC) Team, Workplace Justice; Sexual Harassment in the Workplace, (Washington, DC: National Women's Law Center, 2016), Pg. 1
} 
forms as unwelcome sexual advances and request for any sexual favors verbally or physically, and this sexual harassment definition can be different from one country to another depends on the culture they have. To avoid this kind of harassment in the work place, they pointed out the mechanism which applied in companies in Malaysia such as; clear notice to not doing any act subjected to sexual favors, clear definition about sexual harassment, the procedures to make a report if it happened, certain punishment to doers or to those who made a fake report, and full protection and recovery guarantee for the victims. ${ }^{9}$

Joni Hersch, said in his paper that in term of sexual harassment, women usually are facing a higher risk than men, many cases are underreported because the victims are likely being subject to retaliation. Form the surveys conducted in Europe and the US, he pointed out two obvious points. First, women are commonly a victim. Second, sexual harassment rates vary widely. For example, based on surveys, in 11 European countries, $30-50 \%$ of women are harassed, while a nationa survey of women in Austria found that $81 \%$ and in Sweden was found that only $2 \%$ had been harassed. These differences between countries may reflect the different culture in what behaviours are defined as sexual harassment, also, differ in survey methodologies, sampled population and time period covered are among the causes. From international survey data, John figured out that the victims of sexual harassment are those who younger, holding a lower position jobs, working with or be supervised by the opposite sex, and especially for women, those who work in male dominated occupations. ${ }^{10}$

In order to discourage sexual harassment, there are several guidelines put by certain companies which can be used as general guidelines, for example what Student Legal Services of Edmonton mentioned there, how to avoid a sexual harassment in workplace, such as: the workers should act professionally and with authority, it is good to be polite but not overly friendly, avoid giving any personal details or social life, not being alone with the person, even, when having meal together, they must be sure that both parties know it is for business purposes and not pleasure. Try to avoid any kind of personal favors, be professional ad keep conversations to work and things related to work only, and lastly, inform the person if any discomfort feeling happened and ask them to not continue the act. ${ }^{11}$

Actually, as Islam does not forbid women to be in public, Islam also provides many preventions to protect the believer, especially women, in this case. And this prevention steps should come from both gender. First, prevention step is to lower the gaze. Second, covering aurah properly. Third, maintaining the ordinance of speech by

\footnotetext{
${ }^{9}$ Zakaria Ismail, Abdul Malik Habib Mohd, Malani Achro, Gangguan Seksual di Tempat Kerja; Defenisi, Kesan dan Langkah Mengatasinya, pg. 7.http://repo.uum.edu.my/449/1/Zakaria_Ismail.pdf accessed on: 3/5/2018.

${ }^{10}$ Joni Hersch, Sexual Harassment in The Workplace, (Germany: IZA World of Labor, 2015), pg. 14.

${ }^{11}$ Student Legal Services of Edmonton Team, A Guide, A Guide To The Law In Alberta Regarding Sexual Harassment in The Workplace,(Edmonton: Alberta Human Rights Commision, 2008) Pg. 4-5.
} 
speaking with a proper tone. Not too soft to the opposite gender. Fourth, refrain ikhtilator non syar'i intermingling between sexes. All these four steps must be applied by both gender in order to maintain the work stability and keep the work place to be a safe place also for women.

As stated in Ibn Ashur saying his commentaries book for verse:"Now when he arrived at the wellsof Madyan, he found there a large group of men who were watering [their herds and flocks]; and at some distance from them he came upon two women who were keeping back their flock. He asked [them]: "What is the matter with you?" They answered: "We cannot water [our animals] until the herdsmen drive [theirs] home-for [we are weak and] our father is a very old man."(Qur'an, surah al-Qasas: 23).

He said, based on the story mentioned, it is not forbidden for women to be in public, the same ayah also said their appearance in public is only allowed if they cover all part which should be covered. Besides, this ayah also said about modesty, that modesty is a fundamental thing should be learned by all people and here mentioned it will be beautiful if it possessed by women.

Islam has allowed women to be a part of public since long time ago. It was clearly mentioned in al-Qasas: 23. The verse was telling us about Prophet Syuaib's daughters whose going out from their home feeding their sheep which is known as a job that time. Ibn Ashur said this ayah can be the proof that women are allowed to step on career world and strive in the way of living. By this ayah as well it was clear that the women are allowed to manage their financial matters. ${ }^{12}$ One of Indonesian scholars who was famous with his works in many fields, Hasbi As-shiddiqie, also said the same thing. In his tafsir about Hijab verses in surah al-Nür: 31, he commented that as long as women can cover their aurah properly (their entire body excluded face and both hands) they may do all kinds of activities, jobs, visiting the public places, such as education places, mosques, and involved in the carrier world, whether the job is in a formal form or informal. As it was permissible to appear themselves in public, they also have rights to act and free to speak their own opinions in politics, economics and social. ${ }^{13}$

In Surah al-Naḥl: 97, Allah said "Whoever does righteous deeds, whether male or female, provided he is a believer, We shall surely grant him a new life, a life that is good, and We will certainly reward such people according to the noblest of their deeds in the hereafter" (Al-Nahl:97), here, Quraish Shihab commented that this verse is among the verses which asserted the equality between man and woman. The word "man" which means "whosoever" included both gender and also emphasized by mentioning the word "Żakarin" - men and "unśa" -women. What he wants to stress here is that women are also obliged to take their parts in advantageous activities for

\footnotetext{
${ }^{12}$ Muhammad Eltahir Ibn Muhammad Ibn Muhammad Eltahir Ibn Ashur Eltunisi, Tahrir wa Tanwir, (Tunis: Addar Attunisiyah Linnashr, 1984) Vol. 20, Pg. 101.

${ }^{13}$ Muhammad Hasbi Ash-Shiddieqy, Tafsir Al-Qur'anul Madjid An Nur, (Jakarta: Cakrawala Publishing, 1432H/2011M), Vol. 3, Pg. 101.
} 
themselves, their family and their community. ${ }^{14}$ And working in order to achieve better quality of life is included in the advantageous activities.

Also, In his commentaries about al-Aḩāab: 33 "Stay in your homes and do not display your finery as women used to do in the days of ignorance (pre-Islamic days); establish Salah, pay Zakah, and obey Allah and His Rasool. O women of the household of Rasool, Allah only intends to remove uncleanliness from you and to purify you completely"(Al-Aḩzāb: 33) this verse said that the women should stay quite in their place and not to show themselves dazzlingly as in the Jahiliyyah time, Quraish highlighted several thought by contemporary Muslim scholar such as Al Mawdudi and Sayyid Quthb who are saying that women are allowed to go outside of their houses to fulfill their necessities and needs, and household is main duty to the women as the word 'waqarna' means staying quietly, but it doesn't mean that they are not allowed to leave the house. They may do the duty outside and leave the house but the duty in the house is priority. ${ }^{15}$ In his other book, Quraish added his thought by tagging Abu Zahrah's opinion that Islam does not objected women to step their feet in career life, but they have to put in their mind that life career outside the house is not their main duty as women is the center in the family, ${ }^{16}$ in short, he said women have their right to work as long as the job needs them or they are in need to those jobs. ${ }^{17}$

\section{Dual role conflicts}

However, there were researches coming through this topic. Siti Mahmudah did some research with the family in Pasuruan, one district in East Java Indonesia, which came to the result that the family with female workers as a sustenance may elevated the level of harmony in family. She pointed out that the most problems rooted from financial problem which is low family income can invite a chaos in family. ${ }^{18} \mathrm{M}$. Sholakhuddin also stated in his thesis that financial side might be the best support to the harmonious family, but religious or spiritual side is the most fundamental to attain a sakinah, mawaddah and rahmah family. ${ }^{19}$

In the terms of children upbringing, allegedly, there will be some gap between a working mother and their kids which may cause a negative impression in their relationship and in the process of upbringing and nurturing because lack of attention

${ }^{14}$ M. Quraish Shihab, Tafsir Al-Misbah Pesan, Kesan dan Keserasian Al-Qur'an, (Jakarta: Lentera Hati, 2002), Vol. 6, Pg. 720.

${ }^{15}$ M. Quraish Shihab, Tafsir Al-Misbah Pesan, Kesan dan Keserasian Al-Qur'an, (Jakarta: Lentera Hati, 2002), Vol. 10, Pg. 469.

${ }^{16}$ M. Quraish Shihab, Perempuan, (Jakarta: Penerbit Lentera Hati, 9 ${ }^{\text {th }}$ Edition, 1435/2014), Pg. 399.

${ }^{17}$ M. Quraish Shihab, Membumikan Al-Qur'an: Fungsi dan Peran Wahyu Dalam Kehidupan Masyarakat, (Bandung: PT. Mizan Pustaka, $1^{\text {st }}$ Edition, 14134/2013), Pg. 429.

${ }^{18}$ Siti Mahmudah, Perbedaan Keharmonisan Keluarga Antara Wanita Menikah Yang Bekerja dan MEnikah Yang Tidak Bekerja di Desa Tidu Kecamatan Pohjentrek Kabupaten Pasuruan,(Malang: Fakultas Psikologi, Universitas Islam Negeri Maulana Malik Ibrahim Malang).

${ }^{19}$ M. Sholakhuddin, Dampak Perempuan Bekerja Terhadap Keharmonisan Keluarga Pada Pasangan Muda, Undergraduate Thesis, (Semarang: Jurusan Akhwal Al-Syakshiyyah Fakultas Syari'ah Institut Agama Islam Negeri Walisongo Semarang, 2012) Pg. 75. 
from the mother as they only have a limited time meeting each other. ${ }^{20}$ However, some literatures found and mentioned that a working mother had a positive impact in children character building. As said by Santrock in a research by Ravika, for those kids who are belong to working mother are not necessarily experienced by lack of attention and care. Somehow, mother's present tend to create an independency in the children. ${ }^{21}$ Asrori said as being stated by Ravika that independency in some way determined by genetic. The parents who has a high independency frequently will be imitated by their children. Then, those working women are inclined to have this nat ure of self-independence with high possibilities might grow the same nature in the children as a habit. ${ }^{22}$ This result also amplified by another research by Mastauli Siregar who did a study to 25 working mother in Medan, North Sumatera, Indonesia which resulted that working mother's duty in public sector did not disturb any domestic duty they have, as they are working in public and still able to manage all the home affairs and also taking care about their kid's education. Being a working mother also can build a good mother-kids relationship as they will always value a quality time they have as their presence is more important than their presents. ${ }^{23}$

But, there, Muhammad Rusli explained the negative impact of working mother in his thesisand this negative side will have a serious impact to family and society. For the family- kids and husband included- those kids and husbands will be neglected by working women, he said. Also the sustainability of family life will be distracted if the mother is a carrier woman, because she will be very busy and tend to abandon the family, he asserted. For the society, Muhammad Rusli pointed two points the cause of being a high education and carrier women. First, it will decrease the job field for men which lead to make a number of male unemployment increasing. Second, the career women tend to delay marriage with the assumption they are too selective in term of choosing spouses. Another crucial thing is, he mentioned that men will be unwilling to take career women as a wife who's having higher education and income than them because of their inferiority. ${ }^{24}$ Although this stigma was well spread among the society, it is better forevery men and women, as goodMoslem and asa good community member, tobelief about the discretion about sustenance and spouse all was well planned by God, and it is human who put an effort into having a good discretion should be strong. Second, those women -who are hired by a company and cause the increasing

\footnotetext{
${ }^{20}$ M. Sholakhuddin, Dampak Perempuan Bekerja Terhadap Keharmonisan Keluarga Pada Pasangan Muda, Undergraduate Thesis, (Semarang: Jurusan Akhwal Al-Syakshiyyah Fakultas Syari'ah Institut Agama Islam Negeri Walisongo Semarang, 2012) Pg. 73.

${ }^{21}$ Ravika Geofanny, Perbedaan Kemandirian Anak Usia Dini Ditinjau Dari Ibu Bekerja dan Ibu Tidak Bekerja (di Kecamatan Samarinda kota), PSIKOBORNEO, Volume 4, Nomor 4, 2016 Pg. 719.

${ }^{22}$ Ravika Geofanny, Perbedaan Kemandirian Anak Usia Dini Ditinjau Dari Ibu Bekerja dan Ibu Tidak Bekerja (di Kecamatan Samarinda kota),Psikoborneo, Volume 4, Nomor 4, 2016 Pg. 718.

${ }^{23}$ Mastauli Siregar, Keterlibatan Ibu Bekerja Dalam Perkembangan Pendidikan Anak, Jurnal Harmoni Sosial, Volume II, No. 1, September 2007, Pg. 16.

${ }^{24}$ Muhammad Rusli, Wanita Karir Perspektif Hukum Islam (Studi Kasus Di Kecamatan Rappocini Kota Makassar), Tesis Pascasarjana Bidang Hukum Syariah,(Makassar: Universitas Islam Negeri Alauddin Makassar, 2016) Pg. 51
} 
of unemployed male number- surely have a certain ability that fulfill the company requirement, instead of dissuading women from jobs, why not working to improve selfquality, education and skills until it meets the requirements and fulfill the company criteria?And last, it was also most welcomed to upgrade self-confidence toward these women because well educated women certainly know how to respect their spouse by giving them something that need to be respected.

This was in line with what Muslim scholars focus on, men hold the higher position in family also to unsure its sustainability, then their authorization is needed in every actions their women take including stepping in the career world. In the same time, women should be educated well that once they come to family life, the family will become their first and any other than that is considered as a second. As quoted from Quraish Shihab, after obtaining the permission from their husband, by working outside, the women should not neglect their duties toward their family and kids, they must pay extra attention over the quality and quantity of togetherness among the member of family. ${ }^{25}$

In the verse about husband authorization in An-Nisa: 34, Allah mentioned that $\mathrm{He}$ has put certain qualities and advantages for both male and female. Later, Qurtubi said that the word of "qawwām" or special authorizations come in meanings, one of them is husband hold a full responsibility of his wife in term of wealth, health discipline also education which lead the wife to obey her husband. ${ }^{26}$ From here can be drawn that husband has such authorization to approve or not to approve his wife from going outside for work, as the responsible of sustaining the family is on his shoulder. Then, as long as his permission is given, working outside is permissible for his women.

\section{Findings}

As many problems caused by working women in public as mentioned, it does not mean that women are subjected as source of this chaos which lead to strictly forbid them appearing themselves in public. From what stated from several verses about education, duties, and rights, it was clear that Islam treated both genders equally as to be educated and to acquire knowledges is obligatory for both genders. The same thing came up with duties and rights. Although, it is not an obligatory for women to come out and earn a living for the family, but it is acceptable if the valid reason is existed. According to that there are several conditions must be followed. Firstly, the authorization from husband is obtained, as, respectfully, husband is the leader and has a total responsibility for sustainability of family life. Next, be alert to hijab matters included lowering gaze, humble and well behaved attitude, clothing and outfit.

\footnotetext{
${ }^{25}$ M. Quraish Shihab, Perempuan, (Jakarta: Penerbit Lentera Hati, $9^{\text {th }}$ Edition, 1435/2014), Pg. 405.

${ }^{26}$ Qurtubi, alJami' Li Ahkam Al-Qur'an, (Cairo: Dar Al Maktabah Al Masriyyah, 2 ${ }^{\text {nd }}$ Edition, 1384H/1964M), Vol. 5, Pg. 168.
} 


\section{REFERENCES}

Ash-Shiddieqy, Hasbi, Tafsir Al-Qur'anul Madjid An Nur, Jakarta: Cakrawala Publishing, 2011.

Geofanny, Ravika, Perbedaan Kemandirian Anak Usia Dini Ditinjau Dari Ibu Bekerja dan Ibu Tidak Bekerja (di Kecamatan Samarinda kota), PSIKOBORNEO, Volume 4, Nomor 4, 2016.

Hidayati, Nurul, Beban Ganda Perempuan Bekerja (Antara Domestik dan Publik), Jurnal Muwazah, 2015.

Hersch, Joni. Sexual Harassment in The Workplace, Germany: IZA World of Labor, 2015.

Ibn 'Aṣur, Muhammad Eltahir Ibn Muhammad Ibn Muhammad Eltahir Eltunisi, Tahrìr wa Tanwir, Tunis: Addar Attunisiyah Linnashr, 1984.

Ismail, Zakaria. Habib Mohd, Abdul Malik. Achro, Malani. Gangguan Seksual di Tempat Kerja; Defenisi, Kesan dan Langkah Mengatasinya, pg. 7. http://repo.uum.edu.my/449/1/Zakaria_Ismail.pdf accessed on: 3/5/2018.

Mahmudah, Siti, Perbedaan Keharmonisan Keluarga Antara Wanita Menikah Yang Bekerja dan Menikah yang Tidak Bekerja di Desa Tidu Kecamatan Pohjentrek Kabupaten Pasuruan, Fakultas Psikologi, Universitas Islam Negeri Maulana Malik Ibrahim Malang.

Majid, Fitria, Faktor-Faktor yang Mempengaruhi Keputusan Perempuan Berstatus Menikah Untuk Bekerja (Studi Kasus: Kota Semarang), Undergraduate Thesis, Semarang: Fakultas Ekonomika dan Bisnis, Universitas Diponegoro, Semarang, 2012.

Rusli, Muhammad, Wanita Karir Perspektif Hukum Islam (Studi Kasus Di Kecamatan Rappocini Kota Makassar), Tesis Pascasarjana Bidang Hukum Syariah, Universitas Islam Negeri Alauddin Makassar, 2012.

Shihab, Quraish, Perempuan, Jakarta: Penerbit Lentera Hati., 2014.

Shihab, Quraish, Tafsir Al-Misbah Pesan, Kesan dan Keserasian Al-Qur'an, Jakarta: Lentera Hati, 2002.

Shihab, Quraish, Membumikan Al-Qur'an: Fungsi dan Peran Wahyu Dalam Kehidupan Masyarakat, Bandung: PT. Mizan Pustaka, 2013.

Sholakhuddin, M, Dampak Perempuan Bekerja Terhadap Keharmonisan Keluarga Pada Pasangan Muda, Undergraduate Thesis, Semarang: Jurusan Akhwal AlSyakshiyyah Fakultas Syari'ah Institut Agama Islam Negeri Walisongo Semarang, 2012.

Siregar, Mastauli, Keterlibatan Ibu Bekerja dalam Perkembangan Pendidikan Anak, Jurnal Harmoni Sosial, Volume II, No. 1, 2017.

Qurtubi, Al-Jāmi' Li Ahkkām Al-Qur'ān, Cairo: Dār Al-Maktabah Al-Massriyyah, 2 ${ }^{\text {nd }}$ Edition, 1384H/1964M.

Ema Tusianti, dkk, Kajian Awal Indeks Ketimpangan Gender 2016, Badan Pusat Statistik, 2016.

Student Legal Services of Edmonton Team, A Guide To The Law In Alberta Regarding Sexual Harassment in The Workplace, Edmonton: Alberta Human Rights Commision, 2008.

National Women's Law Center (NWLC) Team, Workplace Justice; Sexual Harassment in the Workplace, Washington, DC: National Women's Law Center, 2016. 